\title{
Disentangling the effects of group size and density on shoaling decisions of three-spined sticklebacks (Gasterosteus aculeatus)
}

\author{
Joachim G. Frommen • Meike Hiermes •
}

Theo C. M. Bakker

Published online: 22 July 2009

(C) Springer-Verlag 2009

\section{Erratum to: Behav Ecol Sociobiol \\ DOI 10.1007/s00265-009-0767-9}

The original version of this article unfortunately contained a mistake. The received date was incorrect. Please note that the correct received date is August 292008.

The online version of the original article can be found at http://dx.doi. org/10.1007/s00265-009-0767-9

J. G. Frommen $(\bowtie) \cdot$ M. Hiermes $\cdot$ T. C. M. Bakker

Institute for Evolutionary Biology and Ecology,

University of Bonn,

An der Immenburg 1,

53121 Bonn, Germany

e-mail: j.frommen@klivv.oeaw.ac.at

J. G. Frommen

Konrad Lorenz Institute for Ethology,

Austrian Academy of Sciences,

Savoyenstr. 1a,

1160 Vienna, Austria 